International Journal of Civil Engineering and Technology (IJCIET)

Volume 9, Issue 10, October 2018, pp. 1498-1507, Article ID: IJCIET_09_10_150

Available online at http://www.iaeme.com/ijciet/issues.asp?JType=IJCIET\&VType=9\&IType $=10$

ISSN Print: 0976-6308 and ISSN Online: 0976-6316

CIAEME Publication

Scopus Indexed

\title{
EFFECT OF PALM OIL AND CATTLE WASTES COMBINATION ON GROWTH AND PRODUCTION OF SWEET CORN
}

\author{
Akhmad Rifai Lubis, Armaniar, Abdul Hadi Idris, Maimunah Siregar, Rusiadi, \\ Marahadi Siregar, Martos Hafena, A. P. U. Siahaan, Muhammad Iqbal \\ Universitas Pembangunan Panca Budi, Medan, Indonesia \\ Meriksa Sembiring \\ Universitas Quality Medan, Medan, Indonesia
}

\begin{abstract}
The purpose of this study was to determine liquid palm oil mill waste (LPKS) combined with cattle waste (LTS) on the growth and yield of sweet corn plants. The field trial was conducted in Complete Randomized Block Design (CRBD) with three replication and two factors. Whereas, first factor was used palm oil mill waste (LPKS) mixing with cattle waste (LTS) at 2 levels namely: P1 (Solid: Solid), P2 (Liquid: Liquid) and the second factor was used the combined of LPKS and LTS in percentage (\%) which consists of 5 various namely; C1 (100: 0), C2 (70: 30), C3 (50: 50), C4 (30: 70) and C5 (0: 100). Land with 125 meters square was divided 30 subplots into three replications which $1.25 m \times 1.5 \mathrm{~m}$ every subplot. The corn crops were planted direct system in the hole with two seeds. The plot was given basic fertilizer with Urea $(150 \mathrm{~kg} / \mathrm{ha}), T S P(100 \mathrm{~kg} / \mathrm{ha})$ and $\mathrm{KCl}(100 \mathrm{~kg} / \mathrm{ha})$. Application of fertilizers was conducted one week after planting. Parameters were measured plant height, yield component (cob diameter) and yield. Data were analyzed using ANOVA if the founded significant was continued with DMRT at $p<0.05$. The results showed that there was a significant effect for all parameters measured; plant height, yield component (cob diameter) and yield. The first factor was shown that P1 its' better than P2. The same result with the second factor was the significant difference among various treatment with $C 1$ was better as compared among them, respectively. Unlike interaction of two factors, there was unsignificantly in $p>0.05$ at DMRT. In this study, our suggested that the application of P1 (solid: solid) and C1 (100:0) can be used the application in sweet corn to increase the yield increase the yield.
\end{abstract}

Key words: LPKS, LTS, combination fertilizer, yield.

Cite this Article: Akhmad Rifai Lubis, Armaniar, Abdul Hadi Idris, Maimunah Siregar,

Rusiadi, Marahadi Siregar, Martos Hafena, A.P.U. Siahaan, Muhammad Iqbal, Meriksa

Sembiring, Effect of Palm Oil and Cattle Wastes Combination on Growth and Production of

Sweet Corn, International Journal of Civil Engineering and Technology (IJCIET) 9(10), 2018, pp. 1498-1507.

http://www.iaeme.com/IJCIET/issues.asp?JType=IJCIET \&VType=9\&IType=10 


\section{INTRODUCTION}

North Sumatra one of the largest oil palm plantation in Sumatra Island, with a total area of 405,799.34 hectares and the yield of 5,428,535.14 tons of Fresh Fruit Bunches (FFB). It gives a huge and positive contribution [1]-[10] to people's welfare, especially in North Sumatra Province and nationally provide the additional foreign exchange. The palm oil mill produces waste in the form of liquid and which has a negative impact on the community in the form of waste that is still high in COD and BOD because it has not been processed optimally by Factory Palm Mill [11]-[14] Oil palm industry waste consists of solid waste in the Palm Oil Mill Effluent (POME) and liquid waste which is the final result of the palm oil processing process [15]-[21]. Palm oil mill waste generally can still be used as a base for organic fertilizer because it has high organic matter content to be used as fertilizer [22]-[26].

The development of beef cattle breeding in North Sumatra for the past five years has experienced a rapid increase in population with an average annual population increase of $10.37 \%$. The number of the beef cattle population in 2014 was 646,749 tails [27]. Production of solid waste (dirt) of an adult cattle is $4,000 \mathrm{~kg} /$ year/head and liquid waste (urine) 1000 liters/ year/head, so it is very potential to be used as a primary material for making organic fertilizer. Waste produced by livestock (both solid and liquid can be used as organic fertilizer for plants)

The nutrient content of each waste is different by having the advantages of each [28]. Of the types of waste that are combined with various percentages will produce organic fertilizer. Organic fertilizers that contain more nitrogen are key to increasing corn production [29]-[31]. The absorption of $\mathrm{N}$ by the corn plant takes place during its growth. Therefore, to get good results, nitrogen nutrients in the soil must be sufficiently available during the growth phase [32]-[34].

\section{METHODOLOGY}

This experiment was carried out with Complete Randomized Block Design (CRBD) three replications and two factors measurement [35]. Factor I: the combination of palm oil mill waste (LPKS) and cattle waste (LTS) with the symbol (P) consists of 2 combined, namely: P1 (solid: solid), P2 (Liquid: liquid). factor II: various variation with percentage(\%) consists of 5 various: C1 (100: 0), C2 (70: 30), C3 (50: 50), C4 (30: 70) and C5 (0: 100). After mixing two component and before application of the first factor, this material was done analyzed of nutrient content with Spectrophotometry Kjeldahl and AAS method.

\subsection{Method}

The extent of the influence of solid and liquid combination fertilizers between LPKS and LTS on the growth and production of sweet corn. The benefits of research such as:

- Determining the combination of oil mill waste (LPKS) and cattle waste (LTS) can be used to increase sweet corn crop.

- As an information material for farmers for the use of fermented waste in increasing agricultural production of corn crops.

\subsection{Research Site}

This research is the land of Sei Village, Send Market IV, Sunggal District, Deli Serdang Regency, North Sumatra. This research was carried out starting from April to July 2018. 


\subsection{Research Material}

Formulation of the formula is a waste mixture with a ratio by the treatment with the addition of $0.5 \%$ sugar drops, $0.25 \%$ bioactivator. Then the mixture in each treatment is stirred until blended. The mixture in a tightly closed container (anaerobic) for three weeks can be used as fertilizer.

\subsection{Parameters Observed}

The parameter tested is the nutrient content of each fertilizer that is successful, plant height, yield component (cob diameter) and yield.

\section{RESULT AND DISCUSSION}

\subsection{Laboratory Analysis}

The results of the laboratory analysis of the nutrient content of organic fertilizers for each treatment (combination of LPKS and LTS waste) can be seen in Table 1. It shows that the highest C-organic content, n-total, P205, K2O in the form of the solid mixture (p1) versus liquid (P2) except ph, is higher in $\mathrm{P} 2$.

Table 1. The average nutrient content of organic fertilizer combined with palm oil mill waste (LPKS) and cattle waste (LTS).

\begin{tabular}{lccccc}
\hline Treatment & $\begin{array}{c}\text { C-Organic } \\
(\mathbf{\%})\end{array}$ & $\begin{array}{c}\text { N-total } \\
(\mathbf{\%})\end{array}$ & $\begin{array}{c}\text { P2O5 } \\
(\mathbf{\%})\end{array}$ & $\begin{array}{c}\text { K2O } \\
(\mathbf{\%})\end{array}$ & pH \\
\hline Mixed Combination (P) & & & & \\
P1 & 38.77 & 0.66 & 0.38 & 0.46 & 7.35 \\
P2 & 6.50 & 0.18 & 0.05 & 0.41 & 8.15 \\
\hline Average & 38.77 & 0.66 & 0.38 & 0.46 & 7.35 \\
Stdev & 22.82 & 0.34 & 0.24 & 0.03 & 0.56 \\
\hline \multicolumn{5}{r}{ Percentage of mixture (C) } \\
C2 & 28.84 & 0.65 & 0.25 & 0.21 & 7.89 \\
C3 & 28.31 & 0.45 & 0.19 & 0.36 & 7.84 \\
C4 & 25.73 & 0.42 & 0.26 & 0.48 & 8.14 \\
C5 & 19.63 & 0.37 & 0.15 & 0.49 & 7.79 \\
\hline Average & 15.32 & 0.27 & 0.23 & 0.67 & 7.86 \\
Stdev & 23.57 & 0.43 & 0.22 & 0.44 & 7.90 \\
\hline \multicolumn{2}{c}{ C = Combination Persentage LPKS with LTS } & & & \\
\hline
\end{tabular}

The results of the statistical analysis of each percentage of the combination of waste there are differences in nutrient content. The highest $\mathrm{C}$-Organic content and $\mathrm{N}$-total were obtained in $100 \%$ LPKS $(\mathrm{C} 1)$ but the highest $\mathrm{K} 2 \mathrm{O}$ was obtained at $\mathrm{C} 2$ (70: 30). The percentage of the combination of C5 waste (100\% Urine) for C-Organic, N-total and P2O5 is the lowest except for $\mathrm{K} 2 \mathrm{O}$ content. $\mathrm{C}$-Organic content, $\mathrm{N}$-total in combination fertilizer decreases in percentage (LPKS), less, when P2O5, K2O generally increases with increasing LTS.

\subsection{Plant Growth}

The Result Average growth of stem height and diameter of sweet corn plants (Table 2) from the effect of form and percentage of the combination of palm oil mill waste (LPKS) with cattle waste (LTS) at 2, 4 and 6 weeks after planting as shown in table 2. The use of a combination of palm oil mill effluent (LPKS) with cattle waste (LTS) from the effect of the combination form on plant growth analysis results shows that plant height at 2 to 4 weeks after planting has an effect that is not real, but at 6 the effect of giving influential combination 
fertilizers that are significantly different. With the highest plant height from the effect of combination organic fertilizer is a combination of palm oil mill waste (LPKS-solid) with cattle waste (LTS-solid) B1 an average of $198.62 \mathrm{~cm}$ significantly different than the use of a combination of LPKS-liquid waste with liquid LTS (B2) on average $186.79 \mathrm{~cm}$. Table $2 \mathrm{can}$ also be seen that the highest effect of the percentage of the combination of LPKS and LTS produced in C1 treatment (100\% LPKS) is not significantly different from C2 and C3.

Table 2 Average growth of plant height $(\mathrm{cm})$ and stem diameter of corn plants from the influence of LPKS and LTS combination fertilizers.

\begin{tabular}{lcccccc}
\hline \multicolumn{1}{c}{$\begin{array}{c}\text { Factor of } \\
\text { Treatment }\end{array}$} & $\begin{array}{c}\text { Height } \\
\mathbf{2}\end{array}$ & $\begin{array}{c}\text { Plant } \\
\mathbf{4}\end{array}$ & $\mathbf{6}$ & $\begin{array}{c}\text { Diameter } \\
\mathbf{2}\end{array}$ & $\begin{array}{c}\text { Stem } \\
\mathbf{4}\end{array}$ & $\mathbf{6}$ \\
\hline $\begin{array}{l}\text { Combination Form } \\
\text { (B) }\end{array}$ & & & & & & \\
Solid: Solid (B1) & $29.74 \mathrm{a}$ & $77.48 \mathrm{a}$ & $198.62 \mathrm{a}$ & $1.68 \mathrm{a}$ & $2.08 \mathrm{a}$ & $2.34 \mathrm{a}$ \\
Liquid ; Liquid (B2) & $30.66 \mathrm{a}$ & $73.99 \mathrm{a}$ & $165.92 \mathrm{~b}$ & $1.59 \mathrm{a}$ & $1.86 \mathrm{a}$ & $1.88 \mathrm{~b}$ \\
\hline \multicolumn{2}{l}{ Percentage: LPKS : LTS (C) } & & & & & \\
$100: 00(\mathrm{C} 1)$ & $15.79 \mathrm{a}$ & $81.52 \mathrm{a}$ & $207.60 \mathrm{a}$ & $1.58 \mathrm{a}$ & $2.13 \mathrm{a}$ & $2.30 \mathrm{a}$ \\
$70: 30(\mathrm{C} 2)$ & $15.54 \mathrm{a}$ & $80.49 \mathrm{a}$ & $197.14 \mathrm{ab}$ & $1.52 \mathrm{a}$ & $1.94 \mathrm{a}$ & $2.18 \mathrm{ab}$ \\
$50: 50(\mathrm{C} 3)$ & $14.77 \mathrm{a}$ & $74.06 \mathrm{a}$ & $184.09 \mathrm{abc}$ & $1.67 \mathrm{a}$ & $1.84 \mathrm{a}$ & $2.14 \mathrm{ab}$ \\
$30: 70(\mathrm{C} 4)$ & $14.62 \mathrm{a}$ & $71.80 \mathrm{a}$ & $168.22 \mathrm{bc}$ & $1.63 \mathrm{a}$ & $2.05 \mathrm{a}$ & $2.04 \mathrm{bc}$ \\
$00: 100(\mathrm{C} 5)$ & $14.78 \mathrm{a}$ & $70.80 \mathrm{a}$ & $154.32 \mathrm{c}$ & $1.79 \mathrm{a}$ & $1.90 \mathrm{a}$ & $1.88 \mathrm{c}$ \\
\hline
\end{tabular}

The same letter notation in the same column is not real at the $5 \%$ level. The lowest plant height produced in C5 treatment (100\% LTS), was not significantly different from C4 and C3 treatments, but significantly different from $\mathrm{C} 1$ and $\mathrm{C} 2$. The use of a combination of LPKS with LTS affects the growth of stem diameter, and the results of the analysis are seen in 2 to 4 weeks of effect which is not significant, but at six most a significant effect $(p<0.05)$. The largest stem diameter is obtained by the use of solid form LPKS and LTS (B1) with a mean of $2.34 \mathrm{~cm}$ while the liquid form (B2) averages $1.88 \mathrm{~cm}$ giving influential combination fertilizers significantly different. The percentage of the combination of LPKS and LTS at six had a significantly different effect on the diameter of the most response on the use of $100 \%$ LPKS (C1) with the same ability as C2 and C3 treatment and significantly different from C4 and C5 (lowest diameter).

\subsection{Yield}

Yield in this study includes ear diameter, production/sample, and yield/plot and the results of the analysis show significant differences in the effect of the type of waste combination (B) and the percentage of waste combination (C). The average diameter corn cob and yield production can be seen in Table 3. The effect of the combination of solid LTS (B1) LPKS on the diameter and length of cob from the results of the analysis gave a significant effect $(\mathrm{p}$ $<0.05$ ), where the Solid Combination B1 with an average diameter of $4.69 \mathrm{~cm}$ and cob length $16.66 \mathrm{~cm}>$ combination of Liquid (B2) with average diameter is $4.45 \mathrm{~cm}$ and length of pole is $13.83 \mathrm{~cm}$. The percentage of the combination of LPKS with LTS for the diameter of the cob is not significant $(\mathrm{p}>0.05)$ while the length of the cob is significantly different. The longest ear lengths produced in the use of treatment $100 \%$ LPKS (C1) with ear lengths averaging 17.57 $\mathrm{cm}$ were not significantly different from C2 (70\% LPKS: 30\% LTS) and C3 (50\%: 50\%), but significantly different from $\mathrm{C} 4$ and $\mathrm{C} 5$ (the ear length is lower. Table 3 shows that the treatment of the use of a combination of solid LPKS and LTS waste (B1) is significantly different and more than the liquid form (B2) against the number of rows/cobs. showed no significant difference ( $p>0.05$ ) with an average number of bari / cob a $12.73 \mathrm{~cm}$ to $13.47 \mathrm{~cm}$. 
Table 3 Average diameter Corn Cob and Sweet Corn yield from the influence of organic fertilizer combined with palm oil waste (LPKS) with cattle waste (LTS) at harvest time.

\begin{tabular}{lccccc}
\hline Perlakuan & $\begin{array}{c}\text { Diameter } \\
\text { Tongkol } \\
(\mathbf{c m})\end{array}$ & $\begin{array}{c}\text { Panjang } \\
\text { Tongkol } \\
(\mathbf{c m})\end{array}$ & $\begin{array}{c}\text { Jumlah baris } \\
\text { per tongkol }\end{array}$ & Produksi/ & Produksi \\
\hline \multicolumn{2}{c}{ Bentuk Kombinasi (B) } & & & & \\
Padat : Padat & & & & & \\
(B1) & $4.69 \mathrm{a}$ & $16.66 \mathrm{a}$ & $13.37 \mathrm{a}$ & $193.84 \mathrm{a}$ & $9.20 \mathrm{a}$ \\
Cair ; Cair (B4) & $4.45 \mathrm{~b}$ & $13.83 \mathrm{~b}$ & $12.91 \mathrm{~b}$ & $114.14 \mathrm{~b}$ & $7.16 \mathrm{~b}$ \\
\hline \multicolumn{2}{l}{ Persentase LPKS $:$ LTS $(\mathrm{C})$} & & & & \\
$100: 00(\mathrm{C} 1)$ & $4.73 \mathrm{a}$ & $17.57 \mathrm{a}$ & $13.47 \mathrm{a}$ & $186.81 \mathrm{a}$ & $9.12 \mathrm{a}$ \\
$70: 30(\mathrm{C} 2)$ & $4.72 \mathrm{a}$ & $16.43 \mathrm{ab}$ & $13.43 \mathrm{a}$ & $179.74 \mathrm{ab}$ & $8.72 \mathrm{ab}$ \\
$50: 50(\mathrm{C} 3)$ & $4.53 \mathrm{a}$ & $15.34 \mathrm{abc}$ & $13.07 \mathrm{a}$ & $152.06 \mathrm{ab}$ & $8.53 \mathrm{abc}$ \\
$30: 70(\mathrm{C} 4)$ & $4.50 \mathrm{a}$ & $14.02 \mathrm{bc}$ & $13.00 \mathrm{a}$ & $131.07 \mathrm{ab}$ & $6.98 \mathrm{bc}$ \\
$00: 100(\mathrm{C} 5)$ & $4.37 \mathrm{a}$ & $12.86 \mathrm{c}$ & $12.73 \mathrm{a}$ & $120.26 \mathrm{~b}$ & $7.54 \mathrm{c}$ \\
\hline
\end{tabular}

The same letter notation in the same column is not real at the 5\% level. Table 3 is the result of the effect of shapes and percentage of combinations shows a significant effect on the diameter parameters of the cob and production. The form of solid x solid combination (B1) is the highest in each parameter compared to the use of liquid $x$ liquid waste (B2). While the percentage of waste treatment that decreases the use of decreasing factory waste results in lower production and smaller diameter of cob, but the treatment of $100 \%$ use of livestock waste (C5) is better compared to the use of $30 \%$ of factory waste and $70 \%$ of livestock waste (C4). The treatment of different plant waste combinations is obtained by different contents. Different nutrient content, especially N-total in the sweet corn crop, influences plant growth, Figure 1, while production is affected by P2O5 nutrient content (Graph 2). From Figure 1, it can be seen that the $\mathrm{N}$-total content in combination treatment affects plant growth, with higher $\mathrm{N}$-total content giving higher growth. Likewise, the effect of P2O5 on combination fertilizers affects production, which in the presence of higher $\mathrm{P} 2 \mathrm{O} 5$ nutrient content provides greater production the same different signal is not real at the $5 \%$ level.

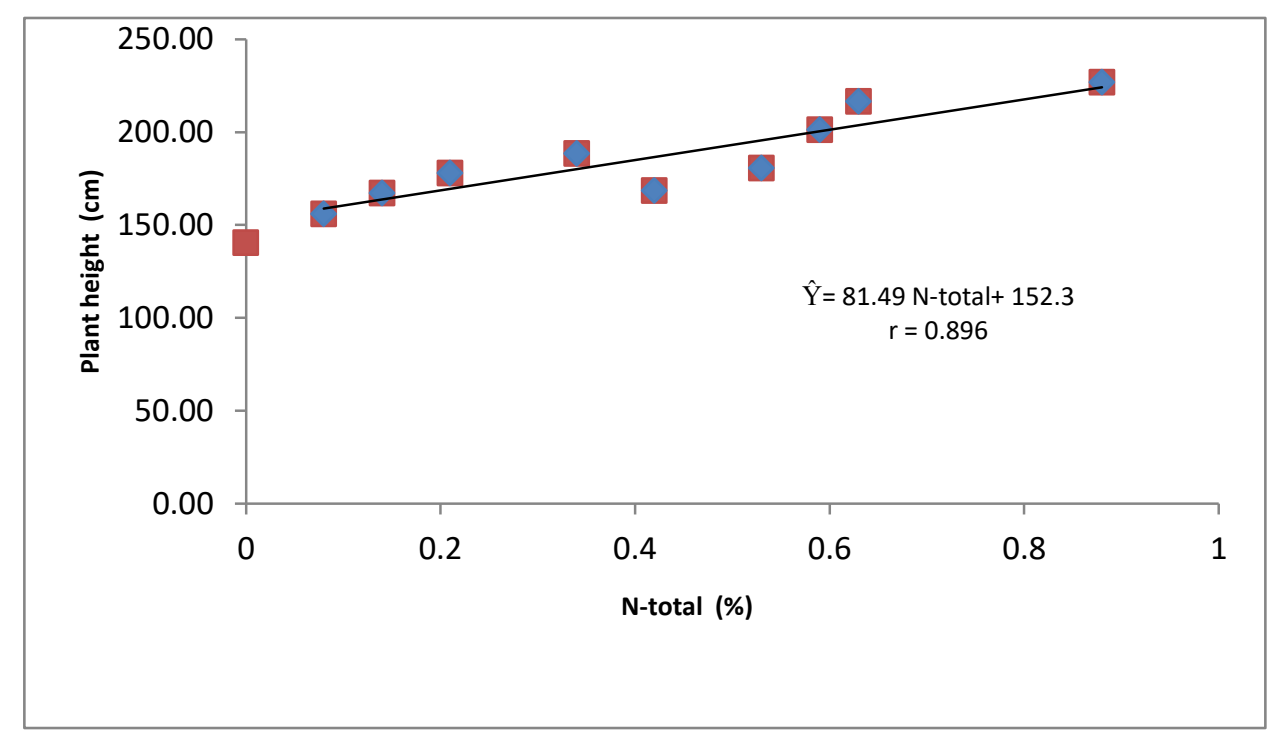

Figure 1 Effect of N-total nutrients on plant height 
Martos Hafena, A.P.U. Siahaan, Muhammad Iqbal, Meriksa Sembiring

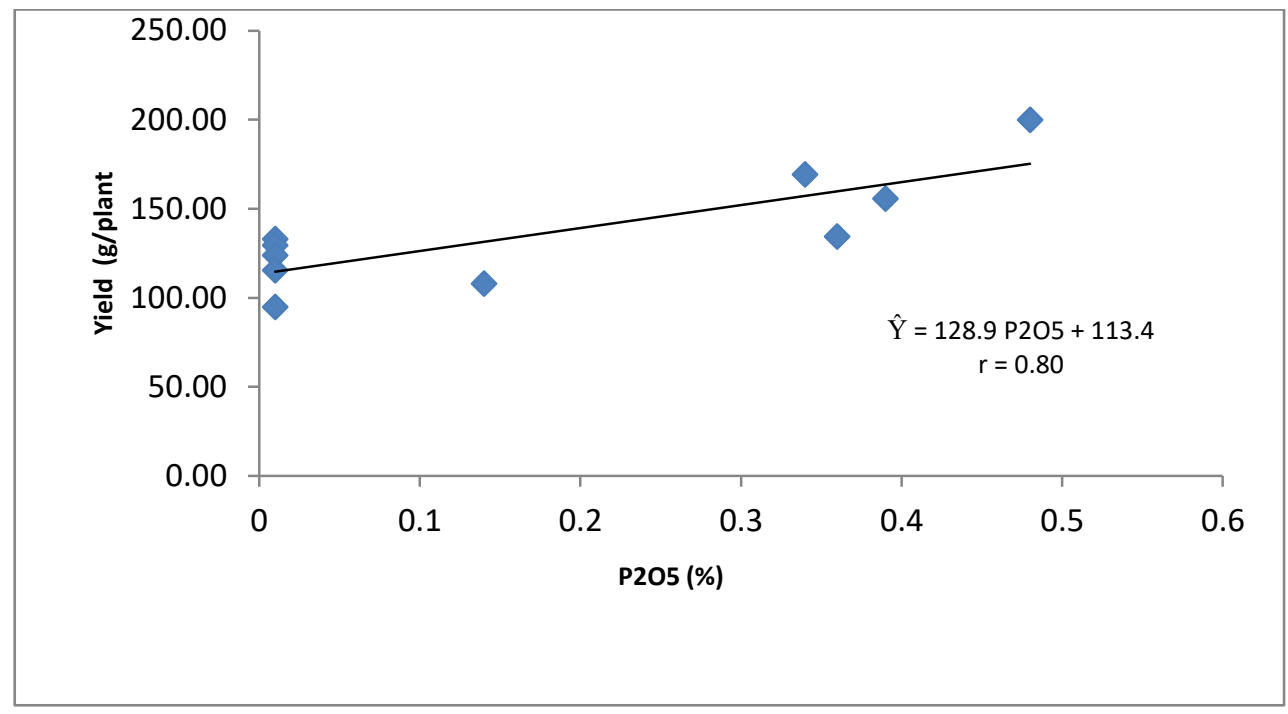

Figure 2. Effect P205 nutrient on yield/plant

Based on Table 2 it can be seen that the P2O5 level on P1 (solid) is greater than that of B2 (liquid), while in Figure 2 describes the changes in yield/plants from the influence of P2O5 levels. Based on the diameter of the affecting production ( $\mathrm{g} / \mathrm{plant})$, when the diameter is affected by nutrient content in the combination fertilizer. To find out the changes in product/sample from the influence of ear diameter can be seen in Figure 3.

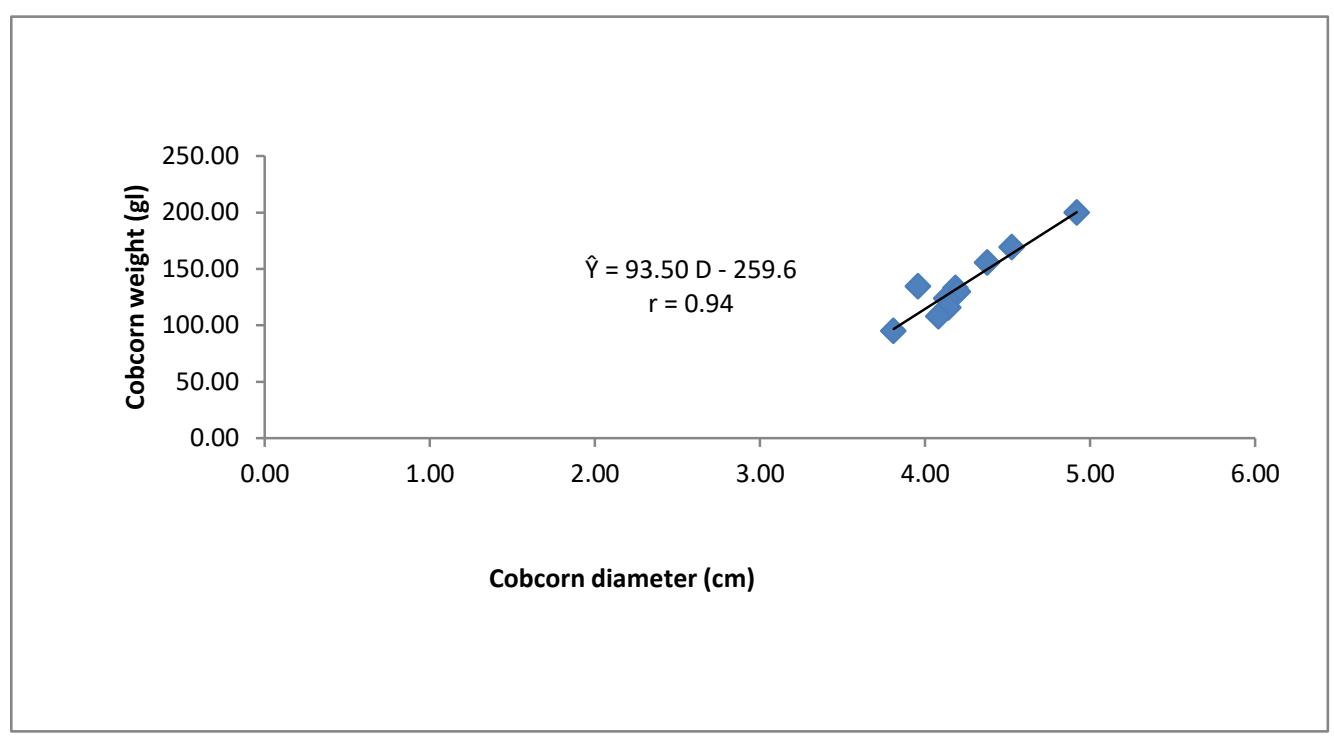

Figure 3 Effect cobcorn diameter on weight (cob/plant)

Table 2 and Figure 3, it is explained that the diameter of the cob closely influences the production while the ear diameter is obtained by the addition of nutrient elements provided through combination organic fertilizer. The most significant changes in production are influenced by the combination of B1 and B2 (solid : solid and liquid : liquid) while the effect of the percentage of combination changes based on mixed materials (substitution).

\subsection{Discussion}

The combination of organic fertilizer $(\mathrm{P})$ and the percentage of waste combination $(\mathrm{C})$ affects the production of corn plants, where the content of organic fertilizer $\mathrm{N}$ can increase crop productivity, it can be seen that the high $\mathrm{N}$ content (Table 1) gives growth and production 
(Table 2 ) Organic fertilizers, in general, can improve soil physical, chemical, and biological properties. With good soil conditions will create a growing environment that is suitable for plant growth, which is reflected in the appearance of plants in the form of high, and good wet weight of plants. The role of organic matter on the physical properties of the soil is to make the soil a crumb structure, as well as the aeration of the soil to be better because of porosity or pore space increases. Soil aeration is related to water content, O2, N2, and CO2 gas in the soil, which is very influential on the development of the roots and life of soil microorganisms. Provision of good organic fertilizer is very supportive in this study because the soil where the study is dry land with dense, hard and clay soil conditions and low C-organic content. Nutrient input on the land causes the low $\mathrm{C}$-organic content only in the form of inorganic fertilizer without being balanced with organic fertilizer. The solid and hard soil conditions, among others, are caused by a land treatment system that always uses a tractor. With the large pressure of the heavy equipment will cause the soil to experience solidification and hardness, which in turn leads to a decrease in soil fertility so that the addition of organic matter is very helpful in improving and improving land productivity. The land with high organic matter content is easier to treat than on land with low organic matter content. It is related to the function of each fertilizer on crop production [36]. Organic fertilizers, in general, can improve soil physical, chemical, and biological properties. The good soil conditions will create a growing environment that is suitable for plant growth, which is reflected in the appearance of plants in the form of changes in growth and production. It is a result of the fact that highly increased plant growth requires more nitrogen uptake. However, nitrogen loss increases when the ability of the soil in immobilization is exceeded [37]. The condition of organic fertilizer from fermentation by microorganisms spurred to make a breakthrough by maintaining soil fertility, improving soil structure, enriching food ingredients in the soil, and neutralizing chemicals or poisons in the soil. Utilization of manure can also reduce the use of fertilizer by $50 \%$ for one hectare of agricultural land [38]. Factors that influence the N-Total value are the organic material, if the organic material is high, the $\mathrm{N}$-Total value is also high, and vice versa. This is consistent with the statement of Kemas [39] which states that if an increase in organic matter occurs, $\mathrm{N}$ in the soil will also increase. Factors affecting $\mathrm{N}$ availability are microorganisms, both those that live freely and those that are associated with plants. Nitrogen can enter through rainwater in the form of nitrates. This number is very dependent on place and climate [40]. The content of C-organic in a combination waste fertilizer is significant for plant height growth, where the higher the C-Organic content gives higher plant height. As long as $\mathrm{C}$-organic is due to the organic matter will experience a process of decomposition gradually, due to the use of carbon nutrients by microorganisms in getting energy for their lives through the process of respiration. It gives the impact of the organic material will experience an increase in the decomposition process [41]. Compost quality is influenced by the type and quality of the constituent material, as well as the quality of the composting process. The composting process is influenced by several parameters, such as particle size, water content, screening, embankment formation, aeration, etc. [42]. The strategy to accelerate the process of bio-decomposition of organic matter is carried out by utilizing lignin and cellulose (cellulolytic) microbes which are generally from the fungi group and are known to show the most significant bio-decomposition activity [43].

\section{CONCLUSIONS}

The combination of palm oil mill waste (LPKS) with cattle waste (LTS) solid x solid form (P1) is the most significant nutrient content and produces the highest production compared to the use of liquid $x$ liquid form (P2). The percentage of the combination of different Palm Oil Mill (LPKS) and Cattle Waste (LTS) wastes influences growth and production, but to get the best is to increase the percentage of solid waste from palm oil mill effluent. .The provision of 
combination fertilizer for Palm Oil Mill (LPKS) with Cattle Livestock Waste (LTS) does not give significant different effects, but maximum production can be achieved by using C2B2 (70\% LPKS with 30\% LTS). Nutrients in the combination waste fertilizer in this study have different effects on the growth and production of sweet corn plants; further research is needed on different plant testing and doses.

\section{REFERENCES}

[1] N. Fadilah, J. M. Saleh, H. Ibrahim, and Z. A. Halim, "Oil palm fresh fruit bunch ripeness classification using artificial neural network," in 2012 4th International Conference on Intelligent and Advanced Systems (ICIAS2012), 2012, pp. 18-21.

[2] A. H. A. Aziz et al., "Design of a capacitive sensor for oil palm fresh fruit bunch maturity grading," in 2014 2nd International Conference on Electronic Design (ICED), 2014, pp. 443-445.

[3] N. Jamil, A. Mohamed, and S. Abdullah, "Automated Grading of Palm Oil Fresh Fruit Bunches (FFB) Using Neuro-fuzzy Technique," in 2009 International Conference of Soft Computing and Pattern Recognition, 2009, pp. 245-249.

[4] W. S. Purba et al., "Relationships Among Knowledge, Attitude And Behavioral Intention of Waste Management Technology," Int. J. Civ. Eng. Technol., vol. 9, no. 9, pp. 792-798, 2018.

[5] A. H. Lubis, S. Z. S. Idrus, and A. Sarji, "ICT Usage Amongst Lecturers and Its Impact Towards Learning Process Quality," vol. 34, no. 1, pp. 284-299, 2018.

[6] M. D. T. P. Nasution, Y. Rossanty, P. B. Sari, and A. P. U. Siahaan, "Online Shoppers Acceptance: an Exploratory Study," Int. J. Civ. Eng. Technol., vol. 9, no. 6, pp. 793-799, 2018.

[7] Y. Rossanty, S. Aryza, M. D. T. P. Nasution, and A. P. U. Siahaan, "Design Service of QFC And SPC Methods in the Process Performance Potential Gain and Customers Value in a Company," Int. J. Civ. Eng. Technol., vol. 9, no. 6, pp. 820-829, 2018.

[8] M. Furqan et al., "A Review of Prim and Genetic Algorithms in Finding and Determining Routes on Connected Weighted Graphs," Int. J. Civ. Eng. Technol., vol. 9, no. 9, pp. $1755-1765,2018$.

[9] S. Aryza, M. Irwanto, Z. Lubis, A. P. U. Siahaan, R. Rahim, and M. Furqan, "A Novelty Design of Minimization of Electrical Losses in A Vector Controlled Induction Machine Drive," in IOP Conference Series: Materials Science and Engineering, 2018, vol. 300, no. 1.

[10] K. E. Anyaoha, R. Sakrabani, K. Patchigolla, and A. M. Mouazen, "Evaluating oil palm fresh fruit bunch processing in Nigeria," Waste Manag. Res., vol. 36, no. 3, pp. 236-246, Mar. 2018.

[11] S. Bahri, E. Saputra, I. Detrina, Yusnitawati, and Muhdarina, "Bio oil from palm oil industry solid waste," in Proceedings of the International Conference on Energy and Sustainable Development: Issues and Strategies (ESD 2010), 2010, pp. 1-3.

[12] A. K. S. Kartina and M. H. N. Suhaila, "Conversion of waste cooking oil (WCO) and palm fatty acid distillate (PFAD) to biodiesel," in 2011 3rd International Symposium \& Exhibition in Sustainable Energy \& Environment (ISESEE), 2011, pp. 42-44.

[13] A. P. U. Siahaan et al., "Combination of Levenshtein Distance and Rabin-Karp to Improve the Accuracy of Document Equivalence Level," Int. J. Eng. Technol., vol. 7, no. 2.27, pp. 17-21, 2018. 
[14] S. Sulaiman, Abdul Aziz Abdul Raman, and Mohammed Kheireddine Aroua, "Coconut waste as a source for biodiesel production," in 2010 2nd International Conference on Chemical, Biological and Environmental Engineering, 2010, pp. 254-256.

[15] V. Grigaitiene, A. Tamosiunas, V. Valincius, and P. Valatkevicius, "Water vapor plasma torch for synthesis gas production from organic waste," in 2014 IEEE 41st International Conference on Plasma Sciences (ICOPS) held with 2014 IEEE International Conference on High-Power Particle Beams (BEAMS), 2014, pp. 1-1.

[16] A. N. A. Shakir, M. A. Sohaimi, D. N. A. Wahid, and J. Salihon, "Effects of variations in palm oil mill effluent (POME) on carbon dioxide sequestration by microalgae and their optimisation," in 4th IET Clean Energy and Technology Conference (CEAT 2016), 2016, p. 86 (5 .)-86 (5 .).

[17] M. Kismurtono, H. Julendra, E. Mahajoeno, and M. Korniawan, "Development of enhanced biogas production from palm oil mill effluent (POME)," in 2016 International Conference on Cogeneration, Small Power Plants and District Energy (ICUE), 2016, pp. $1-7$.

[18] A. Novalina et al., "Confirmatory Factor Analysis Specimen in Calculating Independence Element of Coastal Woman," Int. J. Civ. Eng. Technol., vol. 9, no. 9, pp. 1632-1644, 2018.

[19] S. Suroso et al., "Autoregression Vector Prediction on Banking Stock Return using CAPM Model Approach and Multi-Factor APT," Int. J. Civ. Eng. Technol., vol. 9, no. 9, pp. 1093-1103, 2018.

[20] P. Dauvergne, "The Global Politics of the Business of 'Sustainable' Palm Oil," Glob. Environ. Polit., vol. 18, no. 2, pp. 34-52, May 2018.

[21] J.-Y. Ma and Z.-Y. Ma, "Investigation on Incineration of Salty Organic Wastewater," in 2009 3rd International Conference on Bioinformatics and Biomedical Engineering, 2009, pp. $1-4$.

[22] T. Eddy, B. Alamsyah, S. Aryza, and A. P. U. Siahaan, "An Effect Phenomena Circle Living Field in Secanggang Langkat," Int. J. Civ. Eng. Technol., vol. 9, no. 7, pp. 15751580, 2018.

[23] Y. Chong Tan, F. Mavondo, and S. Worthington, "Organisational capabilities and relationship quality," Asia Pacific J. Mark. Logist., vol. 23, no. 2, pp. 152-164, Mar. 2011.

[24] A. Ikhwan, M. Yetri, Y. Syahra, and J. Halim, "A Novelty of Data Mining for Promoting Education based on FP-Growth Algorithm," Int. J. Civ. Eng. Technol., vol. 9, no. 7, pp. 1660-1669, 2018.

[25] K. Cholapandian and B. Mythily, "Development of nanocomposites bio-organic fertilizer," in 2016 2nd International Conference on Advances in Electrical, Electronics, Information, Communication and Bio-Informatics (AEEICB), 2016, pp. 460-463.

[26] N. Thilagavathi, T. Amudha, and N. Sivakumar, "Computational perspective on organic farming - A survey," in 2017 IEEE Technological Innovations in ICT for Agriculture and Rural Development (TIAR), 2017, pp. 22-27.

[27] C. Thoroughgood, "Animal Husbandry: Aquaculture Versus Agriculture," in Proceedings OCEANS '83, 1983, pp. 993-997.

[28] A. Y. Sangodoyin, "Nutrient benefits and environmental aspects of land disposal of livestock waste," Environ. Manag. Heal., vol. 7, no. 1, pp. 33-38, Mar. 1996.

[29] M. Akil, "Aplikasi pupuk urea pada tanaman jagung," in Prosiding Seminar Nasional Serealia, 2009. 
Akhmad Rifai Lubis, Armaniar, Abdul Hadi Idris, Maimunah Siregar, Rusiadi, Marahadi Siregar, Martos Hafena, A.P.U. Siahaan, Muhammad Iqbal, Meriksa Sembiring

[30] Suwardi and R. Efendi, "Efisiensi penggunaan pupuk $\mathrm{n}$ pada jagung komposit menggunakan bagan warna daun.," in Prosiding Seminar Nasional Serealia, 2009.

[31] Rusiadi et al., "Dependence of poverty dependence on Indonesian economic fundamentals: Sfavar approach," Int. J. Civ. Eng. Technol., vol. 9, no. 6, 2018.

[32] Y. Sutoro and SoelaemanIskandar, Budidaya Tanaman Jagung. Bogor: Balai Penelitian Tanaman Pangan Bogor, 1988.

[33] A. Sanusi et al., "GCG Simultaneity Effects, Profit Management And Value Of Indonesian Retail Companies," Int. J. Civ. Eng. Technol., vol. 9, no. 7, pp. 1506-1518, 2018.

[34] A. I. F. Lubis et al., "Strategy for Improving Science and Welfare Through Community Empowerment Technology," Int. J. Civ. Eng. Technol., vol. 9, no. 9, pp. 1036-1046, 2018.

[35] J. A. List, S. Sadoff, and M. Wagner, "So you want to run an experiment, now what? Some simple rules of thumb for optimal experimental design," Exp. Econ., vol. 14, no. 4, pp. 439-457, Nov. 2011.

[36] A. S. Karama, A. R. Marzuki., and I. Manwan, Penggunaan Pupuk Organik Pada Tanaman Pangan. Jakarta: Pusat Penelitian dan Pengembangan Bagian Teknologi Pertanian, 1994.

[37] H. D. Foth, Dasar-Dasar Ilmu Tanah. Jakarta: Erlangga, 1994.

[38] D. K. Kurniawan, "Pengaruh Volume Penambahan Effective Microorganism 4 (EM4)1\% dan Lama Fermentasi Terhadap Kualitas Pupuk Bokashi Dari Kotoran Kelinci Dan Limbah Nangka," J. Ind., vol. 2, 2012.

[39] K. A., Dasar-Dasar Ilmu Tanah. Jakarta: PT. RajaGrafindo Persada, 2005.

[40] N. Hakim et al., Dasar-Dasar Ilmu Tanah. Lampung: Universitas Lampung, 1986.

[41] C. F. Zimmerman, Determination of Carbon and Nitrogen in sediment and particular of Estuarine/coastal Water Using Element Analysis. Ohio: U.S. Environtmental Protection Agency, Cincinnati, 1997.

[42] J. Richard, Longman Dictionary of Applied Linguistics. England: Longman Group Limited, 1985.

[43] Y. A. Hidayati and E. H., "Analisis Kandungan N, P dan K Pada Lumpur Hasil Ikutan Gasbio (Sludge) Yang Terbuat Dari Feses SapiPerah,” J. Ilmu Ternak, 2008. 